\title{
EFFECT OF DIETARY PROTECTED FAT AND ROUGHAGE LEVEL ON GROWTH PERFORMANCE AND CARCASS CHARACTERISTICS OF GROWING-FINISHING LAMBS
}

\section{T.M. El-Bedawy ${ }^{1}$, M.A.I. Salem ${ }^{1}$, Sawsan Ahmed ${ }^{2}$ and H. A.A. Omer $^{2}$}

1- Department of Animal Production, Faculty of Agriculture, Cairo University, Giza, Egypt, 2- Department of Animal Production, National Research Center, Dokki, Cairo, Egypt

\section{SUMMARY}

Sixty male Barki lambs (age 8 month, weight $27.5 \mathrm{Kg}$ ) in six similar groups were fed diets containing $10 \%$ or $30 \%$ berseem hay with 0,4 and $8 \%$ Ca-Soaps for 70 days. Feed intakes and body weight were weekly recorded. At the end of the experiment, three lambs from each group were slaughtered to study the effect of protected fat and roughage levels on carcass characteristics and mutton quality.

Increasing fat level in diet $(P>0.05)$ increased total body weight gain and average daily gain (ADG). The $8 \%$ fat level improved feed conversion ratio (DM and DCP to gain ratio) by $6.4 \%$ and $14.3 \%$, respectively. Lambs fed low roughage- high fat showed better body weight gain (16.76 kg); average daily gain $(240 \mathrm{~g} /$ day) and feed conversion ratio (4.5 DM intake/gain and 0.61 DCP intake/gain). Roughage level had no significant effect on body weight gain, average daily gain and feed conversion ratio.

Dietary fat level or roughage or their interaction had no significant effect on carcass weight and dressing percentage. Feeding rations containing protected fat had no significant effect on physical properties of meat except the increased $(P<0.05)$ tenderness of the eye muscle of sheep fed $8 \%$ fat diets. Protected fat supplement $(P<0.05)$ increased weights of omentum fat, intestinal fat, kidneys fat and total body and ether extract of eye muscle and liver but decreased $(P<0.05)$ protein content of eye muscle. Feeding protected fat had no significant effect on fatty acid composition of eye muscle lipids, except the $(P<0.05)$ higher lauric acid $(C 12: 0)$ of 4\% fat group.

Neither fat nor roughage level had significant effect on eye muscle area, eye muscle weight and physical composition of the best 9,10 and $11^{\text {th }}$ ribs (percentages of lean, fat and bone).

Results of chemical composition of whole 9, 10 and $11^{\text {th }}$ ribs showed that feeding protected fat diets $(P<0.05)$ increased DM and ether extract but decreased $(P<0.05)$ $C P$ percentages compared to the control $(0 \%$ fat $)$. Ash percentage was not significantly changed.

Feeding protected fat to growing lambs resulted in higher average daily gain and higher carcass fats, but it did not alter the percentage of unsaturated fatty acids in carcass fat. Roughage level had no significant effect on either the growth performance or carcass characteristics. (The greater intake of digestible energy by the lambs fed calcium soaps of palm oil may account for the higher average daily gains and fatter carcasses).

Keywords: sheep, calcium soaps, carcass characteristics, meat quality 


\section{INTRODUCTION}

In ruminants, dietary unsaturated fatty acids are extensively biohydrogenated by ruminal microorganisms and the predominant class of fatty acids absorbed are saturated' FA; which favor synthesis of very-low-density lipoprotein (Byers and Schelling, 1988). Dietary modifications to reduce saturated fatty acids and/or increase polyunsaturated fatty acids in tissues therefore, more difficult to achieve in ruminants than in nonruminants. However, modifying tissue lipids can be achieved by feeding ruminants feedstuffs with ruminal escape characteristics (Solomon et al., 1991; Lough et al., 1992).

The objectives of this study were to examine the effects of high-forage diets without or with different levels of protected fat fed on performance and carcass characteristics of growing lambs.

\section{MATERIALS AND METHODS}

Sixty male Barki lambs aged 8 months and averaged $27.5 \mathrm{~kg}$ body weight were randomly divided into six similar groups, each of ten lambs. Lambs were fed at level of $3.5 \% \mathrm{DM}$ of body weight for 70 days six diets containing $10 \%$ or $30 \%$ berseem hay as roughage (low and high roughage levels) and $\mathrm{Ca}$-Soaps with three levels 0,4 and $8 \%$ (low, medium and high fat) or (LF, MF and HF, respectively) of dietary DM. The experimental rations were almost iso-nitrogenous but not iso-energetic. Ingredient, chemical composition and nutritive value of the experimental rations are presented in Table 1.

Animals were weighed once a week before feeding at 8:00 hrs. Fresh water was available for free choice consumption. Feed intakes and body weight were weekly recorded.

Eighteen animals (three from each group) were slaughtered at the end of the experiment to study the effect of feeding protected fat and roughage level on carcass characteristics and mutton quality.

\section{Slaughter technique}

Animals were weighed after 12 hrs fasting, just before slaughtering. After complete bleeding, head, skin and feet were removed and weighed. Internal organs and offals (heart, lungs, liver, testes, spleen, kidneys and digestive tract) were removed and individually weighed. Body fats including tail, momentum, intestinal fat, kidney fat and scalpel separable fats were weighed and represented as a percentage of slaughter weight

\section{The best ribs cut}

The best 9,10 and $11^{\text {th }}$ ribs were removed and kept frozen in polyethylene bags for later physical and chemical analyses. Best ribs were dissected using scalpel into lean, fat and bone. Eye (longissimus dorssi) muscle area was measured in squared centimeters using planimeter (Henderson et al. 1966).

\section{Chemical composition}

Samples of eye muscle lean, liver and heart were dried and analyzed for DM, EE and ash (A.O.A.C., 1984) while CP percentage was calculated by difference (O'Mary 
et al. 1979). Ether extract of lean was used for fatty acid analysis using gas liquid chromatography technique (Mason and Waller, 1964).

Table 1. Ingredient, chemical composition and nutritive value of the experimental rations

\begin{tabular}{lcccccc}
\hline & \multicolumn{3}{c}{ 10\% roughage } & \multicolumn{3}{c}{ 30 \% roughage } \\
\cline { 2 - 7 } Item & \multicolumn{3}{c}{ Calcium soap, \% } & \multicolumn{3}{c}{ Calcium soap, \% } \\
\cline { 2 - 7 } & 0 & 4 & 8 & 0 & 4 & 8 \\
\hline Feed ingredient, \% & & & & & & \\
Concentrate mix. & 89.7 & 85.2 & 81.7 & 73.5 & 70.2 & 66.9 \\
Berseem hay & 10.3 & 10.6 & 10.3 & 26.5 & 25.6 & 25.1 \\
Protected fat & 0 & 4.2 & 8.0 & 0 & 4.2 & 8.0 \\
Chemical analysis, \% & & & & & & \\
DM & 89.32 & 89.52 & 89.48 & 90.68 & 91.06 & 91.45 \\
DM composition\% & & & & & & \\
OM & 94.18 & 93.62 & 93.04 & 93.20 & 92.66 & 92.14 \\
CP & 19.38 & 19.07 & 18.81 & 19.09 & 18.75 & 17.35 \\
EE & 2.90 & 6.37 & 9.84 & 2.65 & 6.12 & 9.59 \\
CF & 5.22 & 5.27 & 5.16 & 9.65 & 9.61 & 9.91 \\
NFE & 66.68 & 62.91 & 59.23 & 61.81 & 58.18 & 55.29 \\
Ash & 5.82 & 6.38 & 6.96 & 6.80 & 7.34 & 7.86 \\
Nutritive value & & & & & & \\
DE Mcal/ kg DM * & 3.291 & 3.531 & 3.638 & 3.061 & 3.338 & 3.470 \\
TDN \% * & 74.16 & 80.19 & 79.64 & 69.01 & 76.68 & 77.62 \\
DCP \% * & 14.11 & 13.88 & 13.48 & 13.08 & 13.48 & 11.96 \\
\hline
\end{tabular}

Concentrate mix., composed of $60 \%$ yellow corn, $20 \%$ soybean meal, $17 \%$ wheat bran, $0.8 \%$ sodium chloride, $1.2 \%$ limestone and $1 \%$ minerals.

* Were determined from digestion trial.

\section{Physical characteristics}

\section{pH value}

Samples of $2 \mathrm{~g}$ of eye muscle lean in $100 \mathrm{ml}$ distilled water were shaken for 10 minutes. The $\mathrm{pH}$ was measured in filtrate using Orion Research (model 201) digital pH meter (Aitken et al. 1962)

\section{Water holding capacity}

Water holding capacity (WHC) \% was determined by weighing about $0.3 \mathrm{~g}$ of eye muscle on filter paper between two glass cover $(20 \times 20 \mathrm{~cm} \times 6 \mathrm{~mm})$ under pressure of one $\mathrm{kg}$ for 10 minutes. Water holding capacity was estimated as weight difference percentage (Grau and Hamm, 1957).

\section{Cooking loss \%}

Samples of lean were cut into $(2 \times 1 \times 1 \mathrm{~cm})$ cubes, weighed and boiled in saline solution ( $9 \mathrm{~g}$ sodium chloride / liter distillated water) for 30 minutes. Cooking loss was calculated as weight difference percentage. 


\section{Tenderness}

Samples which were previously used in cooking loss determination were used to measure tenderness by using $50 \mathrm{lb}$. Warner-Bratzler Shear Force (Grau and Hamm, 1957).

\section{Statistical analysis}

Collected data were subjected to statistical analyzed as two factor factorial analysis of variance (Snedecor and Cochran, 1984). Duncan's Multiple Range Test (Duncan, 1955) was used to separate means when the dietary treatment effect was significant according to the following model:

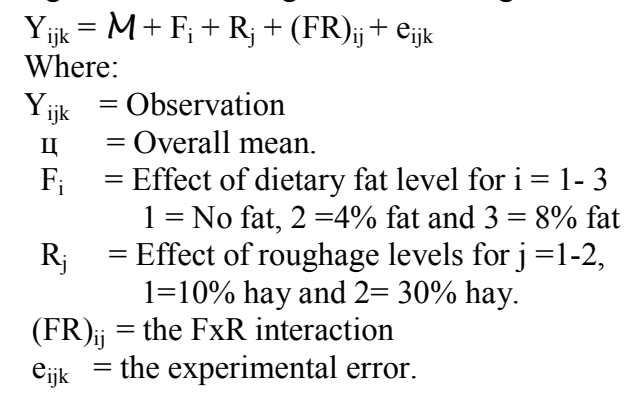

\section{RESULTS AND DISCUSSION}

Daily dry matter and nutrient intakes during the 70-day experimental period are shown in Table 2 . The mean values of concentrate intake by lambs fed high roughage level ranged from 754 to $762 \mathrm{~g} /$ day, while, it ranged from 874 to $912 \mathrm{~g}$ /day for lambs fed low roughage diets. On the other hand, roughage intake ranged from 275 to $285 \mathrm{~g}$ $/ \mathrm{h} /$ day for high roughage level but it ranged from 105 to $111 \mathrm{~g} / \mathrm{h} /$ day for lambs fed low roughage level.

Digestible energy (DE) and TDN intakes were $(\mathrm{P}<0.05)$ higher for protected fat supplemented group than the control (no added fat). Interaction between roughage and fat was not significant on DE and TDN intakes. These results were in agreement with those found by El-Bedawy (1995) that TDN intake increased by fat addition in sheep diets.

No significant differences $(\mathrm{P}>0.05)$ in digestible crude protein (DCP) intake among the experimental groups were detected. Bendary et al. (1994); El-Bedawy et al. (1996b) and El-Bedawy et al. (2004a) reported that fat addition had no significant effect on DCP intake.

Data in Table 3 showed that mean effects of dietary treatments on body weight gain, average daily gain and feed conversion ratio were not significant $(p>0.05)$. However, increasing fat level tended to increase total weight gain and average daily gain (ADG). Contradicting responses in ADG to fat feeding were reported. However, Cameron and Hougue (1968); Zinn (1989); White et al. (1992); Pinosa et al. (1992); Huffman et al. (1992); Maiga et al. (1995); Chrzaszcz et al. (1995) and Wettestein et al. (1999) found that added fat to the diet had no significant effect or decreased average daily gain. El- Bedawy et al. (1996b); Zinn and Plascencia (1996) and 
Plascencia et al. (1999) reported that body weight gain and average daily gain increased by fat supplement.

Table 2. Daily dry matter, energy and nutrient intakes by the experimental groups

\begin{tabular}{|c|c|c|c|c|c|c|c|}
\hline \multirow[t]{2}{*}{ Item } & \multicolumn{3}{|c|}{$10 \%$ roughage diets } & \multicolumn{3}{|c|}{$30 \%$ roughage diets } & \multirow[t]{2}{*}{ SEM } \\
\hline & 0 & 4 & 8 & 0 & 4 & 8 & \\
\hline Av. body weight (kg) & 34.6 & 34.8 & 35.9 & 34.5 & 34.8 & 35.2 & 1.0 \\
\hline Concentrate mix. (g) & 912 & 874 & 882 & 762 & 754 & 758 & 33 \\
\hline Berseem hay $(\mathrm{g})$ & 105 & 109 & 111 & 275 & 275 & 285 & 10 \\
\hline Protected fat (g) & 0 & 43 & 87 & 0 & 45 & 90 & 2 \\
\hline \multicolumn{8}{|l|}{ Dry matter } \\
\hline g/day & 1017 & 1026 & 1080 & 1037 & 1074 & 1133 & 44.0 \\
\hline $\mathrm{g} / \mathrm{kg} \mathrm{W}^{0.75}$ & 71.30 & 71.61 & 73.67 & 72.80 & 74.90 & 78.48 & 3.06 \\
\hline $\mathrm{Kg} / 100 \mathrm{~kg} \mathrm{BW}$ & 2.94 & 2.95 & 3.01 & 3.00 & 3.08 & 3.22 & 0.13 \\
\hline \multicolumn{8}{|l|}{$\mathrm{DE}$ (Mcal) } \\
\hline Mcal/ day & $2.93^{\mathrm{b}}$ & $2.99^{\mathrm{b}}$ & $3.52^{\mathrm{ab}}$ & $2.71^{\mathrm{b}}$ & $3.26^{\mathrm{ab}}$ & $3.90^{\mathrm{a}}$ & 0.21 \\
\hline Mcal/100 kg BW & $8.5^{\mathrm{b}}$ & $8.6^{\mathrm{b}}$ & $9.8^{\mathrm{ab}}$ & $7.9^{\mathrm{b}}$ & $9.4^{\mathrm{ab}}$ & $11.1^{\mathrm{a}}$ & 0.6 \\
\hline Kcal/ Kg W ${ }^{0.75}$ & $205^{\mathrm{b}}$ & $209^{\mathrm{b}}$ & $240^{\mathrm{ab}}$ & $190^{\mathrm{b}}$ & $227^{\mathrm{ab}}$ & $270^{\mathrm{a}}$ & 15 \\
\hline \multicolumn{8}{|l|}{ TDN } \\
\hline g/day & $755^{\mathrm{bc}}$ & $823^{\mathrm{ab}}$ & $860^{\mathrm{a}}$ & $716^{c}$ & $823^{\mathrm{ab}}$ & $879^{\mathrm{a}}$ & 33.5 \\
\hline $\mathrm{g} / \mathrm{kg} \mathrm{W}^{0.75}$ & $52.9^{b c}$ & $57.4^{\mathrm{abc}}$ & $58.7^{\mathrm{ab}}$ & $50.3^{c}$ & $57.4^{\mathrm{abc}}$ & $60.9^{\mathrm{a}}$ & 2.30 \\
\hline $\mathrm{Kg} / 100 \mathrm{~kg} \mathrm{BW}$ & $2.18^{b c}$ & $2.37^{\mathrm{ab}}$ & $2.40^{\mathrm{ab}}$ & $2.07^{\mathrm{c}}$ & $2.36^{\mathrm{ab}}$ & $2.50^{\mathrm{a}}$ & 0.09 \\
\hline \multicolumn{8}{|l|}{$\mathrm{DCP}$} \\
\hline g/day & 143 & 142 & 146 & 136 & 145 & 136 & 6 \\
\hline $\mathrm{g} / \mathrm{kg} \mathrm{W}^{0.75}$ & 10.0 & 9.9 & 10.0 & 9.6 & 10.1 & 9.4 & 0.4 \\
\hline $\mathrm{g} / 100 \mathrm{~kg} \mathrm{BW}$ & 413 & 408 & 407 & 394 & 416 & 387 & 2 \\
\hline
\end{tabular}

$\overline{a, b, c}$ Means in the same row having different superscripts $(\mathrm{P}<0.05)$ differ.

Table 3. Main effects of dietary treatments on body weight gain and feed conversion of the experimental groups

\begin{tabular}{|c|c|c|c|c|c|c|c|}
\hline \multirow{2}{*}{ Item } & \multicolumn{3}{|c|}{ Protected fat level } & \multirow{2}{*}{ SEM } & \multicolumn{2}{|c|}{ Roughage level } & \multirow{2}{*}{ SEM } \\
\hline & LF & MF & $\mathrm{HF}$ & & Low & High & \\
\hline Initial weight, $\mathrm{kg}$ & 27.5 & 27.5 & 27.5 & 0.5 & 27.5 & 27.5 & 0.4 \\
\hline Final weight, kg & 41.6 & 42.1 & 43.5 & 0.9 & 42.6 & 42.2 & 0.8 \\
\hline Gain, kg & 14.1 & 14.6 & 16.0 & 0.7 & 15.1 & 14.7 & 0.6 \\
\hline ADG, g/day & 202 & 209 & 229 & 10 & 217 & 210 & 10 \\
\hline \multicolumn{8}{|c|}{ Feed conversion ratio ( $\mathrm{kg}$ / kg gain) } \\
\hline Dry matter & 5.32 & 5.17 & 5.00 & 0.25 & 5.00 & 5.32 & 0.21 \\
\hline TDN & 3.80 & 4.05 & 3.93 & 0.19 & 3.90 & 3.96 & 0.15 \\
\hline DCP & 0.72 & 0.71 & 0.63 & 0.03 & 0.69 & 0.68 & 0.03 \\
\hline
\end{tabular}

Feeding $8 \%$ fat containing rations insignificantly improved feed conversion ratio (DM and DCP to gain ratio) by $6.4 \%$ and $14.3 \%$, respectively, but decreased TDN conversion ratio by $3.4 \%$. These results might be related to the increase in energy intake of fat supplemented groups, which had not met by parallel increase in ADG 
and/or the possible change in body composition. Christie (1981) reported that dietary fat tended to promote body fat deposition with limited change in ADG.

Feeding high roughage level had no significant effect on body weight gain, average daily gain and feed conversion ratio. Bartle et al. (1994) and Zinn and Plascencia (1996) found that feeding high forage level (30\% alfalfa hay) insignificantly decreased $(\mathrm{P}>0.05)$ final live body weight, body weight gain, average daily gain and feed efficiency compared to low roughage level (10\% alfalfa hay) .

Data in Table 4 showed that there were no interaction between roughage level and supplemental fat (FXR) on growth performance of the experimental groups, but lambs fed low roughage- high fat showed the highest values of body weight gain $(16.8 \mathrm{~kg})$; average daily gain $(240 \mathrm{~g} /$ day) and feed conversion ratio (4.5 DM intake/gain and 0.61 DCP intake/gain). Bartle et al. (1994) and Zinn and Plascencia (1996) found that there were no interactions between forage level and supplemental fat on body weight gain, average daily gain and feed efficiency.

Table 4. Effect of protected fat and roughage level on body weight gain and feed conversion of the experimental groups

\begin{tabular}{lccccccc}
\hline \multirow{2}{*}{ Item } & \multicolumn{3}{c}{ Low roughage } & \multicolumn{3}{c}{ High roughage } & \\
\cline { 2 - 7 } & LF & MF & HF & LF & MF & HF & SEM \\
\hline No., of animals & 10 & 10 & 10 & 10 & 10 & 10 & \\
Initial weight, kg & 27.5 & 27.5 & 27.5 & 27.5 & 27.5 & 27.5 & 0.8 \\
Final weight, kg & 41.7 & 42.1 & 44.3 & 41.6 & 42.2 & 42.8 & 1.3 \\
Gain, kg & 14.2 & 14.6 & 16.8 & 14.1 & 14.7 & 15.3 & 1.0 \\
ADG, kg /day & 203 & 209 & 240 & 201 & 210 & 219 & 10 \\
Feed conversion ratio (kg / kg gain) & & & & & \\
Dry matter & 5.01 & 4.91 & 4.50 & 5.16 & 5.11 & 5.17 & 0.35 \\
TDN & 3.72 & 4.93 & 3.58 & 3.56 & 3.92 & 4.01 & 0.27 \\
DCP & 0.70 & 0.68 & 0.61 & 0.68 & 0.69 & 0.62 & 0.05 \\
\hline
\end{tabular}

Increasing dietary fat level had no significant effect on carcass weight and dressing percentage (Table 5). These results were in agreement with those found by Zinn and Plascencia (1996); and Kerley's (2002) which found that supplemental fat had no significant effect on carcass weight and dressing percentage. However, Mc Cartor and Smith (1978); Zinn (1992) and Bendary et al. (1994) found that hot carcass weight and dressing percentage increased by feeding fat containing rations. On the other hand, Ngidi et al. (1990) recorded that hot carcass weight linearly decreased with increasing calcium soaps of long-chain fatty acids level from $2 \%$ to $6 \%$ in the diet fed to crossbred steers.

Roughage level had no significant effect $(\mathrm{P}>0.05)$ on carcass weight and dressing percentage. These results were in agreement with data obtained by Zinn and Plascencia (1996) that roughage level had no significant effect or decreased carcass weight and dressing percentage.

Data in table 6 showed that there were no interactions between roughage level and supplemental fat level (FXR) on slaughter weight, carcass weight and dressing percentage. 
Table 5. Main effects of dietary treatments on carcass weight and dressing Percentage of the experimental groups

\begin{tabular}{|c|c|c|c|c|c|c|c|}
\hline \multirow{2}{*}{ Item } & \multicolumn{3}{|c|}{ Protected fat level } & \multirow{2}{*}{ SEM } & \multicolumn{2}{|c|}{ Roughage level } & \multirow{2}{*}{ SEM } \\
\hline & LF & MF & $\mathrm{HF}$ & & Low & High & \\
\hline Slaughter weight, kg (SW) & 41.98 & 39.43 & 41.88 & 0.72 & 41.16 & 41.04 & 0.72 \\
\hline Carcass weight, $(\mathrm{kg})$ & 19.48 & 18.67 & 19.85 & 0.39 & 19.51 & 19.15 & 0.35 \\
\hline Dressing percentage & 46.39 & 47.40 & 47.39 & 0.73 & 47.45 & 46.67 & 0.59 \\
\hline
\end{tabular}

Table 6. Carcass weight and dressing percentage of the experimental groups

\begin{tabular}{lccccccc}
\hline \multirow{2}{*}{ Item } & \multicolumn{3}{c}{ Low roughage } & \multicolumn{3}{c}{ High roughage } & \multirow{2}{*}{ SEM } \\
\cline { 2 - 7 } & HF & MF & HF & LF & MF & HF & \\
\hline Slaughter weight, kg & 42.97 & 39.50 & 41.00 & 41.00 & 39.37 & 42.77 & 0.92 \\
Carcass weight, kg & 20.07 & 18.82 & 19.65 & 18.88 & 18.52 & 20.05 & 0.50 \\
Dressing percentage & 46.71 & 47.65 & 47.93 & 46.05 & 47.04 & 46.88 & 1.11 \\
\hline
\end{tabular}

Physical properties as $\mathrm{pH}$, water holding capacity, cooking loss $\%$ and tenderness of the eye muscle of the experimental groups were presented in Table 7. Feeding protected fat containing rations had no significant effect on physical properties of meat, except increased $(\mathrm{P}<0.05)$ tenderness of the eye muscle of sheep fed $8 \%$ fat diets. El-Bedawy et al (1996a) reported higher $\mathrm{pH}$ of the muscle extraction for fat supplemented group being 6.00 compared with 5.78 for the control. However, ElBedawy et al. (2004b) showed that fat supplementation had no significant effect on $\mathrm{pH}$, cooking loss percentage, expressible fluid percentage and fiber diameter.

Roughage level had no significant effect on physical characteristics of the eye muscle of the experimental lamb groups. Data in Table 8 showed that there were no interactions between roughage and supplementary fat levels on $\mathrm{pH}$ values and water holding capacity. While there was significant interaction on cooking loss and tenderness, increasing protected fat with low roughage level increased the tenderness of eye muscle.

Table 7. Main effects of dietary treatments on physical characteristics of the Longissimus dorsi muscle for the experimental groups

\begin{tabular}{lllllllll}
\hline \multirow{2}{*}{ Item } & \multicolumn{3}{l}{ Protected fat level } & \multirow{2}{*}{ SEM } & \multicolumn{3}{c}{ Roughage level } & \multirow{2}{*}{ SEM } \\
\cline { 2 - 3 } & LF & MF & HF & & Low & High & \\
\hline pH & 5.69 & 5.70 & 5.69 & 0.01 & 5.69 & 5.68 & 0.01 \\
Water holding capacity & 18.6 & 19.1 & 17.7 & 1.1 & 18.4 & 18.6 & 0.9 \\
Cooking loss & $42.6^{\mathrm{a}}$ & $39.0^{\mathrm{b}}$ & $41.6^{\mathrm{a}}$ & 0.8 & 41.8 & 40.3 & 0.9 \\
Tenderness & $3.45^{\mathrm{b}}$ & $3.53^{\mathrm{ab}}$ & $3.66^{\mathrm{a}}$ & 0.02 & 3.57 & 3.52 & 0.03 \\
\hline
\end{tabular}

${ }^{\mathrm{a}, \mathrm{b}}$ Means within each treatment having different superscripts $(\mathrm{P}<0.05)$ differ

Protected fat supplement $(\mathrm{P}<0.05)$ increased ether extract content of eye muscle and liver but decreased $(\mathrm{P}<0.05)$ protein content of muscle. Ash content of muscle was lower for the 8\% fat level (Table 9). El-Bedawy (1989); Bendary et al. (1994); El- Bedawy et al. (1996a); El-Bedawy et al. (2004b); Abdelhamid et al. (2003) and El- Kholy et al. (2003) found that feeding fat containing diets for goat, sheep and calves had no significant effect on chemical composition of eye muscle but AboDonia et al. (2003) found that addition of 5\% calcium salts of soap-stock in Ossimi lamb rations $(\mathrm{P}<0.05)$ increased $\mathrm{DM}, \mathrm{EE}$ and ash content of the eye muscle. 
Table 8. Physical characteristics of the longissimus dorsi muscle for the experimental groups

\begin{tabular}{lccccccc}
\hline Item & \multicolumn{3}{c}{ Low roughage } & \multicolumn{3}{c}{ High roughage } & \multirow{2}{*}{ SEM } \\
& LF & MF & HF & LF & MF & HF & \\
\hline pH value & 5.69 & 5.70 & 5.69 & 5.68 & 5.69 & 5.69 & 0.01 \\
Water holding capacity & 18.7 & 19.0 & 17.4 & 18.6 & 19.2 & 17.9 & 1.6 \\
Cooking loss & $42.1^{\mathrm{b}}$ & $38.8^{\mathrm{c}}$ & $44.6^{\mathrm{a}}$ & $43.1^{\mathrm{ab}}$ & $39.3^{\mathrm{c}}$ & $38.6^{\mathrm{c}}$ & 0.76 \\
Tenderness & $3.47^{\mathrm{cd}}$ & $3.55^{\mathrm{bc}}$ & $3.69^{\mathrm{a}}$ & $3.40^{\mathrm{d}}$ & $3.50^{\mathrm{c}}$ & $3.62^{\mathrm{ab}}$ & 0.02 \\
\hline
\end{tabular}

${ }^{\mathrm{a}, \mathrm{b}}$ Means in the same row having different superscripts $(\mathrm{P}<0.05)$ differ.

Roughage level showed no significant effect on chemical composition of eye muscle, liver and heart. Data in Table 10 showed significant $(\mathrm{P}<0.05)$ roughage fat interaction on DM and ash percentages of eye muscle. Lambs those fed low roughage- high fat showed the highest values of EE but lowest ash contents.

Table 9. Main effects of dietary treatments on chemical composition of muscle, liver and heart for the experimental groups

\begin{tabular}{|c|c|c|c|c|c|c|c|}
\hline \multirow{2}{*}{ Item } & \multicolumn{3}{|c|}{ Protected fat level } & \multirow{2}{*}{ SEM } & \multicolumn{2}{|c|}{ Roughage level } & \multirow{2}{*}{ SEM } \\
\hline & LF & MF & $\mathrm{HF}$ & & Low & High & \\
\hline \multicolumn{8}{|l|}{ Eye muscle } \\
\hline DM & 31.85 & 34.08 & 33.69 & 1.17 & 33.58 & 32.83 & 1.01 \\
\hline $\mathrm{CP}$ & $70.29^{\mathrm{a}}$ & $63.30^{\mathrm{b}}$ & $60.45^{\mathrm{b}}$ & 2.20 & 63.75 & 65.62 & 2.27 \\
\hline Ether extract & $26.39 b$ & $33.89 \mathrm{a}$ & $36.72 \mathrm{a}$ & 2.43 & 33.25 & 31.41 & 2.40 \\
\hline Ash & 3.32 & 2.81 & 2.83 & 0.18 & 3.00 & 2.97 & 0.16 \\
\hline \multicolumn{8}{|l|}{ Liver } \\
\hline DM & 30.43 & 29.98 & 30.45 & 0.48 & 29.99 & 30.58 & 0.40 \\
\hline $\mathrm{CP}$ & 83.20 & 81.90 & 80.91 & 0.79 & 82.91 & 81.10 & 0.64 \\
\hline Ether extract & $11.54^{\mathrm{b}}$ & $13.08^{\mathrm{a}}$ & $14.08^{\mathrm{a}}$ & 0.65 & 12.27 & 13.76 & 0.61 \\
\hline Ash & 5.26 & 5.02 & 4.66 & 0.39 & 4.82 & 5.14 & 0.34 \\
\hline \multicolumn{8}{|l|}{ Heart } \\
\hline DM & 28.36 & 27.77 & 26.94 & 1.32 & 28.02 & 27.35 & 1.07 \\
\hline $\mathrm{CP}$ & 57.91 & 54.42 & 60.55 & 3.93 & 56.02 & 59.25 & 3.19 \\
\hline Ether extract & 38.45 & 41.90 & 34.16 & 4.09 & 39.66 & 36.67 & 3.38 \\
\hline Ash & $3.64^{\mathrm{b}}$ & $3.68^{\mathrm{b}}$ & $5.29^{\mathrm{a}}$ & 0.37 & 4.32 & 4.08 & 0.40 \\
\hline
\end{tabular}

${ }^{\mathrm{a}, \mathrm{b}}$ Means within each treatment having different superscripts $(\mathrm{P}<0.05)$ differ.

Main effects of dietary treatments on total body fats are shown in Table 11. Feeding protected fat $(\mathrm{P}<0.05)$ increased weights of omentum fat, intestinal fat, kidneys fat and total body fat. These results were in agreement with those found for sheep (El- Bedawy, 1989) and for steers (Haaland et al., 1981; Zinn, 1992, White et al., 1992 and Bartle et al., 1994 and Zinn and Plascencia, 1996) and for growingfinishing bulls El-Bedawy et al. (2004b). However, Teixeira et al. (1989); Ngidi et al. (1990) and Bock et al. (1991) found that fat supplementation had no significant effect on kidneys fat percentage.

No significant differences in the percentage of total body fat weights to slaughter weight of sheep fed either low or high roughage rations. Bartle et al. (1994) and Zinn 
and Plascencia (1996) found that dietary forage level did not increase or sometimes decreased fat thickness, KPH and carcass fats.

Table 10. Chemical composition of muscle, liver and heart for the experimental groups

\begin{tabular}{lccccccc} 
Item & \multicolumn{3}{c}{ Low roughage } & \multicolumn{3}{c}{ High roughage } & SEM \\
& LF & MF & HF & LF & MF & HF & \\
Eye muscle & & & & & & & \\
DM & 31.72 & 33.35 & 35.67 & 31.99 & 34.80 & 31.70 & 1.52 \\
CP & $70.19^{\mathrm{a}}$ & $66.27 \mathrm{a}^{\mathrm{b}}$ & $54.79^{\mathrm{c}}$ & $70.39^{\mathrm{a}}$ & $60.31 \mathrm{~b}^{\mathrm{c}}$ & $66.13^{\mathrm{ab}}$ & 2.07 \\
Ether extract & $26.35^{\mathrm{c}}$ & $30.71^{\mathrm{bc}}$ & $42.68^{\mathrm{a}}$ & $26.42^{\mathrm{c}}$ & $37.08^{\mathrm{ab}}$ & $30.75^{\mathrm{bc}}$ & 2.24 \\
Ash & 3.46 & 3.02 & 2.53 & 3.19 & 2.61 & 3.12 & 0.20 \\
Liver & & & & & & & \\
DM & $29.12^{\mathrm{b}}$ & $30.48^{\mathrm{ab}}$ & $30.38^{\mathrm{ab}}$ & $31.73^{\mathrm{a}}$ & $29.48^{\mathrm{b}}$ & $30.52^{\mathrm{ab}}$ & 0.47 \\
CP & $82.92^{\mathrm{a}}$ & $83.00^{\mathrm{a}}$ & $82.81^{\mathrm{a}}$ & $83.48^{\mathrm{a}}$ & $80.80^{\mathrm{ab}}$ & $79.01^{\mathrm{b}}$ & 0.66 \\
Ether extract & $11.12^{\mathrm{b}}$ & $12.86^{\mathrm{b}}$ & $12.82^{\mathrm{b}}$ & $11.95^{\mathrm{b}}$ & $13.30^{\mathrm{b}}$ & $16.04^{\mathrm{a}}$ & 0.70 \\
Ash & $5.96^{\mathrm{a}}$ & $4.14^{\mathrm{b}}$ & $4.37^{\mathrm{b}}$ & $4.57^{\mathrm{ab}}$ & $5.90^{\mathrm{a}}$ & $4.95^{\mathrm{ab}}$ & 0.36 \\
Heart & & & & & & & \\
DM & 29.30 & 27.44 & 27.33 & 27.42 & 28.10 & 26.54 & 1.97 \\
CP & 56.84 & 55.687 & 55.53 & 58.98 & 53.18 & 65.57 & 5.58 \\
Ether extract & 40.06 & 40.37 & 38.56 & 36.83 & 43.42 & 29.76 & 5.86 \\
Ash & $3.10^{\mathrm{b}}$ & $3.95^{\mathrm{b}}$ & $5.91^{\mathrm{a}}$ & $4.19^{\mathrm{b}}$ & $3.40^{\mathrm{b}}$ & $4.67^{\mathrm{ab}}$ & 0.42 \\
\hline
\end{tabular}

${ }^{a, b, c}$ Means in the same row having different superscripts $(\mathrm{P}<0.05)$ differ

Data in Table 12 showed that there were no forage- fat interaction on body fat weights. Zinn and Plascencia (1996) reported similar results for steers fed calcium soap.

Table 11. Main effects of dietary treatments on total body fat weights and percentages to the slaughter weight (SW) of the experimental groups

\begin{tabular}{lcccccccc}
\hline \multirow{2}{*}{ Item } & \multicolumn{3}{c}{ Protected fat level } & \multirow{2}{*}{ SEM } & \multicolumn{3}{c}{ Roughage level } & \multirow{2}{*}{ SEM } \\
\cline { 2 - 4 } & LF & MF & HF & & Low & High & \\
\hline Omentum fat $(\mathrm{kg})$ & $0.34^{\mathrm{b}}$ & $0.46^{\mathrm{b}}$ & $0.68^{\mathrm{a}}$ & 0.07 & 0.51 & 0.48 & 0.08 \\
\% of SW & $0.80^{\mathrm{b}}$ & $1.17^{\mathrm{b}}$ & $1.63^{\mathrm{a}}$ & 0.16 & 1.24 & 1.17 & 0.19 \\
Intestinal fat (kg) & $0.50^{\mathrm{b}}$ & $0.70^{\mathrm{a}}$ & $0.76^{\mathrm{a}}$ & 0.05 & 0.62 & 0.68 & 0.07 \\
\% of SW & $1.18^{\mathrm{b}}$ & $1.78^{\mathrm{a}}$ & $1.81^{\mathrm{a}}$ & 0.13 & 1.53 & 1.65 & 0.16 \\
Kidneys fat (kg) & $0.22^{\mathrm{b}}$ & $0.23 \mathrm{~b}$ & $0.33^{\mathrm{a}}$ & 0.03 & 0.22 & 0.29 & 0.03 \\
\% of SW & $0.52^{\mathrm{b}}$ & $0.57 \mathrm{~b}$ & $0.79^{\mathrm{a}}$ & 0.08 & 0.53 & 0.71 & 0.07 \\
Tail fat (kg) & 1.05 & 1.29 & 1.42 & 0.13 & 1.35 & 1.15 & 0.12 \\
\% of SW & 2.49 & 3.26 & 3.40 & 0.30 & 3.28 & 2.82 & 0.28 \\
Total body fat (kg) & $2.11^{\mathrm{b}}$ & $2.68^{\mathrm{a}}$ & $3.19^{\mathrm{a}}$ & 0.13 & 2.70 & 2.60 & 0.19 \\
\% of SW & $4.99^{\mathrm{b}}$ & $6.78^{\mathrm{a}}$ & $7.63^{\mathrm{a}}$ & 0.34 & 6.58 & 6.35 & 0.47 \\
\hline a,b Means within each treatment having different superscripts $(P<0.05)$ & differ. &
\end{tabular}


Table 12. Total body fat weights and percentages to the slaughter weight (SW) of the experimental groups

\begin{tabular}{lccccccc}
\hline \multirow{2}{*}{ Item } & \multicolumn{3}{c}{ Low roughage } & \multicolumn{3}{c}{ High roughage } & \multirow{2}{*}{ SEM } \\
\cline { 2 - 7 } & LF & MF & HF & LF & MF & HF & \\
\hline Omentum fat (kg) & 0.36 & 0.45 & 0.71 & 0.32 & 0.47 & 0.65 & 0.10 \\
\% of SW & 0.83 & 1.15 & 1.74 & 0.78 & 1.20 & 1.52 & 0.24 \\
Intestinal fat (kg) & $0.53^{\mathrm{ab}}$ & $0.64^{\mathrm{ab}}$ & $0.70^{\mathrm{ab}}$ & $0.46^{\mathrm{b}}$ & $0.76^{\mathrm{a}}$ & $0.82^{\mathrm{a}}$ & 0.07 \\
\% of SW & $1.23^{\mathrm{ab}}$ & $1.63^{\mathrm{ab}}$ & $1.72^{\mathrm{ab}}$ & $1.13^{\mathrm{b}}$ & $1.93^{\mathrm{a}}$ & $1.90^{\mathrm{a}}$ & 0.18 \\
Kidneys fat (kg) & $0.22^{\mathrm{b}}$ & $0.17^{\mathrm{b}}$ & $0.28^{\mathrm{ab}}$ & $0.22^{\mathrm{b}}$ & $0.28^{\mathrm{ab}}$ & $0.38^{\mathrm{a}}$ & 0.04 \\
\% of SW & $0.51^{\mathrm{b}}$ & $0.42^{\mathrm{b}}$ & $0.67^{\mathrm{ab}}$ & $0.53^{\mathrm{b}}$ & $0.71^{\mathrm{ab}}$ & $0.90^{\mathrm{a}}$ & 0.10 \\
Tail fat (kg) & 1.15 & 1.23 & 1.67 & 0.94 & 1.35 & 1.17 & 0.17 \\
\% of SW & 2.67 & 3.11 & 4.05 & 2.30 & 3.42 & 2.75 & 0.38 \\
Total body fat (kg) & $2.26^{\mathrm{cd}}$ & $2.49^{\mathrm{bc}}$ & $3.36^{\mathrm{a}}$ & $1.94^{\mathrm{d}}$ & $2.86^{\mathrm{ab}}$ & $3.02^{\mathrm{ab}}$ & 0.16 \\
\% of SW & $5.24^{\text {cd }}$ & $6.31^{\mathrm{bc}}$ & $8.18^{\mathrm{a}}$ & $4.74^{\mathrm{d}}$ & $7.26^{\mathrm{ab}}$ & $7.07^{\mathrm{ab}}$ & 0.39 \\
\hline a,b,c Means in the same row having different superscripts $(\mathrm{P}<0.05)$ differ &
\end{tabular}

Feeding $4 \%$ or $8 \%$ protected fat containing rations had no significant effect on fatty acid composition of muscle lipids except the $(\mathrm{P}<0.05)$ higher lauric acid $(\mathrm{C} 12: 0)$ of 4\% fat group. Ilian et al. (1988); El- Bedawy et al. (1996a) and Eweedah et al. (1997) found that feeding lambs or bulls fat containing diets had no significant effect on fatty acid composition of eye muscle and carcass lipids. However, Abo- Donia et al. (2003) found that feeding 5\% Ca- Soap containing diets to Ossimi male lambs or buffalo calves slightly increased Oleic acid (C18: 1), Linoleic acid (C18: 2) and Linolenic acid (C18: 3). Roughage level showed no significant effect on fatty acid composition of muscle lipids of the experimental groups (Table 13).

Table 13. Main effects of dietary treatments on fatty acid composition of eye muscle lipids for the experimental groups

\begin{tabular}{lccccccc}
\hline Fatty acid \% & \multicolumn{3}{c}{ Protected fat level } & \multirow{2}{*}{ SEM } & \multicolumn{2}{c}{ Roughage level } & \multirow{2}{*}{ SEM } \\
\cline { 2 - 4 } & LF & MF & HF & & Low & High & \\
\hline C8:0 & 0.21 & 0.22 & 0.19 & 0.02 & 0.20 & 0.21 & 0.02 \\
C10:0 & 0.12 & 0.13 & 0.09 & 0.02 & 0.11 & 0.11 & 0.02 \\
C12:0 & $3.09^{\mathrm{b}}$ & $3.57^{\mathrm{a}}$ & $2.95^{\mathrm{b}}$ & 0.16 & 3.39 & 3.02 & 0.15 \\
C14:0 & 0.68 & 0.54 & 0.49 & 0.06 & 0.63 & 0.51 & 0.05 \\
C16:0 & 23.38 & 25.94 & 24.95 & 0.65 & 24.78 & 24.74 & 0.65 \\
C18:0 & 0.19 & 0.28 & 0.63 & 0.10 & 0.35 & 0.38 & 0.13 \\
C18:1 & 52.58 & 52.20 & 50.27 & 0.88 & 52.20 & 50.27 & 0.82 \\
C18:2 & 4.70 & 4.46 & 4.21 & 0.18 & 4.63 & 4.29 & 0.15 \\
C18:3 & 0.23 & 0.27 & 0.27 & 0.05 & 0.24 & 0.27 & 0.04 \\
Other & 14.82 & 12.39 & 15.95 & 1.14 & 13.47 & 16.20 & 1.06 \\
Total saturated & 27.67 & 30.68 & 29.30 & 0.68 & 29.46 & 28.97 & 0.74 \\
Total unsaturated & 72.33 & 69.32 & 70.70 & 0.68 & 70.54 & 71.03 & 0.74 \\
\hline a,b Means within each treatment having different superscripts $(\mathrm{P}<0.05)$ differ. &
\end{tabular}

Data in Table 14 showed that there were significant roughage $\mathrm{x}$ fat interaction on Capric acid (C10: 0) and Myristic acid (C14: 0). While no interactions were detected on the other fatty acids. The effect of dietary fatty acid would not expected to be great on the fatty acid composition of lean of animals fed fat containing diets because 
of the biohydrogenation in rumen by rumen microbes (El-Meddah et al.1991; Wu and Palmquist 1991; Wu et al. 1991; Ferlay et al.1993 and Doreau et al. 1993).

Table 14. Fatty acid composition of eye muscle lipids of the experimental groups

\begin{tabular}{lccccccc}
\hline Fatty acid, \% & \multicolumn{3}{c}{ Low roughage } & \multicolumn{3}{c}{ High roughage } & \multirow{2}{*}{ SEM } \\
& LF & MF & HF & LF & MF & HF & \\
\hline C8:0 & 0.19 & 0.22 & 0.19 & 0.22 & 0.22 & 0.19 & 0.03 \\
C10:0 & $0.08^{\mathrm{bc}}$ & $0.12^{\mathrm{ab}}$ & $0.12^{\mathrm{ab}}$ & $0.16^{\mathrm{a}}$ & $0.13^{\mathrm{ab}}$ & $0.05^{\mathrm{c}}$ & 0.02 \\
$\mathrm{C} 12: 0$ & $3.38^{\mathrm{ab}}$ & $3.73^{\mathrm{a}}$ & $3.05^{\mathrm{ab}}$ & $2.81^{\mathrm{b}}$ & $3.40^{\mathrm{ab}}$ & $2.84^{\mathrm{b}}$ & 0.19 \\
$\mathrm{C} 14: 0$ & $0.84^{\mathrm{a}}$ & $0.49^{\mathrm{b}}$ & $0.55^{\mathrm{b}}$ & $0.52^{\mathrm{b}}$ & $0.58^{\mathrm{b}}$ & $0.43^{\mathrm{b}}$ & 0.06 \\
$\mathrm{C} 16: 0$ & 22.57 & 25.96 & 25.80 & 24.19 & 25.92 & 24.09 & 0.83 \\
$\mathrm{C} 18: 0$ & 0.21 & 0.18 & 0.66 & 0.18 & 0.38 & 0.60 & 0.15 \\
$\mathrm{C} 18: 1$ & 52.93 & 52.73 & 50.94 & 52.23 & 51.67 & 49.67 & 1.25 \\
C18:2 & 5.12 & 4.52 & 4.24 & 4.28 & 4.39 & 4.18 & 0.20 \\
C18:3 & 0.14 & 0.30 & 0.29 & 0.32 & 0.24 & 0.26 & 0.07 \\
Other & 14.54 & 11.75 & 14.16 & 15.09 & 13.07 & 17.76 & 1.49 \\
Total saturated & 27.27 & 30.70 & 30.38 & 28.07 & 30.63 & 28.20 & 0.95 \\
Total unsaturated & 72.73 & 69.30 & 69.62 & 71.93 & 69.37 & 71.80 & 0.95 \\
\hline
\end{tabular}

${ }^{a, b}$ Means in the same row having different superscripts $(\mathrm{P}<0.05)$ differ.

Data in Table 15 showed that neither fat nor roughage level had significant effect on eye muscle area, eye muscle weight and physical composition of the best ribs (percentages of lean, fat and bone). These results were in agreement with those found by El- Bedawy 1989; White et al. 1992; Zinn 1992; Bartle et al. 1994; Zinn and Plascencia 1996, El- Bedawy et al. 1996a and El-Bedawy et al. (2004b) that feeding fat containing diets to goat, sheep or steers had no significant effect on eye muscle area or physical composition of the best $(9,10$ and 11) ribs. However, El- Kholy et al. (2003) found that 5\% Ca-Soap supplement to buffalo calves $(\mathrm{P}<0.05)$ increased eye muscle area and lean percentage, lean: bone ratio and lean: fat ratio but $(\mathrm{P}<0.05)$ decreased fat and bone percentages. While, Abo- Donia et al. (2003) found that supplementation of $5 \%$ calcium salts of soap stock in Ossimi lamb diets $(\mathrm{P}<0.05)$ decreased lean but increased $(\mathrm{P}<0.05)$ fat percentages with no significant effect on bone percentage. Bartle et al. (1994) and Zinn and Plascencia (1996) found that increasing alfalfa hay level from $10 \%$ to $30 \%$ in steer rations had no significant effect on eye muscle area.

Data in Table 16 showed no significant roughage $\mathrm{x}$ fat interaction on eye muscle area, eye muscle weight and physical composition (lean, fat and bone) of the best ribs. Lambs those fed high roughage- high fat diets recorded the highest values of fat percentage and the lowest value of lean percentages. Bartle et al. (1994) and Zinn and Plascencia (1996) found no significant forage $x$ fat interaction on eye muscle area.

Results of chemical composition of whole 9, 10 and $11^{\text {th }}$ ribs showed that feeding protected fat diets $(\mathrm{P}<0.05)$ increased $\mathrm{DM}$ and ether extract but decreased $(\mathrm{P}<0.05)$ $\mathrm{CP}$ percentages compared to the control (no added fat). While, ash percentage was not significantly changed (Table 15). However Ilian et al. (1988) found that addition of 5\% fat into diets did not affect protein, fat and ash percentages of sheep carcass. Also, Zinn (1992) noticed that feeding finishing steers on $6 \%$ fat containing diets did not influence body composition. Roughage level had no significant effect on chemical composition of the best ribs. 
There were no significant roughage $\mathrm{x}$ fat interactions on chemical composition of the best ribs. Lambs that fed low roughage- high fat diet recorded the highest value of ether extract percentage and the lowest value of crude protein percentage.

Table 15. Main effects of dietary treatments on physical and chemical composition of the best $\left(9,10\right.$ and $\left.11^{\text {th }}\right)$ ribs of the experimental groups

\begin{tabular}{|c|c|c|c|c|c|c|c|}
\hline \multirow[t]{2}{*}{ Item } & \multicolumn{3}{|c|}{ Protected fat level } & \multirow{2}{*}{ SEM } & \multicolumn{2}{|c|}{ Roughage level } & \multirow{2}{*}{ SEM } \\
\hline & LF & MF & $\mathrm{HF}$ & & Low & High & \\
\hline Eye muscle area $\left(\mathrm{Cm}^{2}\right)$ & 21.3 & 21.2 & 20.4 & 1.2 & 20.5 & 21.5 & 1.0 \\
\hline Eye muscle weight (g) & 120 & 108 & 128 & 7 & 125 & 166 & 5 \\
\hline \multicolumn{8}{|c|}{ Physical composition of the best ribs, $\%$} \\
\hline Lean & 63.7 & 62.5 & 59.8 & 1.9 & 62.5 & 61.5 & 1.6 \\
\hline Fat & 22.4 & 24.2 & 26.2 & 2.2 & 23.4 & 25.1 & 1.9 \\
\hline Bone & 13.9 & 13.3 & 14.0 & 1.0 & 14.1 & 13.4 & 0.7 \\
\hline \multicolumn{8}{|c|}{ Chemical composition of the best ribs, $\%$} \\
\hline $\mathrm{DM}$ & $44.2^{\mathrm{b}}$ & $46.7^{\mathrm{a}}$ & $47.6^{\mathrm{a}}$ & 0.9 & 46.6 & 45.8 & 0.9 \\
\hline \multicolumn{8}{|l|}{ DM composition, $\%$} \\
\hline $\mathrm{CP}$ & $49.7^{\mathrm{a}}$ & $44.2^{\mathrm{b}}$ & $42.7^{b}$ & 1.2 & 45.4 & 45.6 & 1.5 \\
\hline Ether extract & $42.6^{\mathrm{b}}$ & $49.3^{\mathrm{a}}$ & $50.6^{\mathrm{a}}$ & 1.4 & 47.8 & 47.1 & 1.6 \\
\hline Ash & 7.7 & 6.5 & 6.7 & 0.4 & 6.8 & 7.2 & 0.3 \\
\hline
\end{tabular}

${ }^{\mathrm{a}, \mathrm{b}}$ Means within each treatment having different superscripts $(\mathrm{P}<0.05)$ differ.

Table 16. Physical and chemical composition of the whole best ribs of the experimental groups

\begin{tabular}{lccccccc}
\hline Item & \multicolumn{3}{c}{ Low roughage } & \multicolumn{3}{c}{ High roughage } & \multirow{2}{*}{ SEM } \\
& LF & MF & HF & LF & MF & HF & \\
Eye muscle area cm & 20.8 & 18.6 & 22.0 & 21.9 & 23.8 & 18.9 & 1.3 \\
Eye muscle weight, g & 135 & 105 & 135 & 105 & 110 & 120 & 7 \\
Physical composition of the best ribs, \% & & & & & \\
Lean & 64.1 & 60.8 & 62.5 & 63.2 & 64.2 & 57.0 & 2.5 \\
Fat & 21.7 & 26.5 & 22.0 & 23.1 & 21.9 & 30.5 & 2.7 \\
Bone & 14.2 & 12.7 & 15.5 & 13.7 & 13.9 & 12.5 & 1.2 \\
Chemical composition & of the best ribs, \% & & & & & \\
DM & $43.9^{\mathrm{b}}$ & $46.1^{\mathrm{ab}}$ & $49.7^{\mathrm{a}}$ & $44.5^{\mathrm{b}}$ & $47.3^{\mathrm{ab}}$ & $45.6^{\mathrm{b}}$ & 1.2 \\
CP & $50.1^{\mathrm{a}}$ & $45.4^{\mathrm{ab}}$ & $40.8^{\mathrm{b}}$ & $49.3^{\mathrm{a}}$ & $43.0^{\mathrm{b}}$ & $44.6^{\mathrm{ab}}$ & 1.7 \\
Ether extract & $42.2^{\mathrm{c}}$ & $48.8^{\mathrm{abc}}$ & $52.4^{\mathrm{a}}$ & $43.1^{\mathrm{bc}}$ & $49.7^{\mathrm{ab}}$ & $48.7^{\mathrm{abc}}$ & 1.9 \\
Ash & 7.7 & 5.8 & 6.8 & 7.7 & 7.3 & 6.7 & 0.5 \\
\hline
\end{tabular}

${ }^{a, b, c, d}$ Means in the same row having different superscripts $\left.\mathrm{P}<0.05\right)$ differ.

\section{Implications}

Feeding diet containing dietary protected fat to growing lambs resulted in higher average daily gain and higher carcass fats but it did not alter the percentage of unsaturated fatty acid in carcass fat. Roughage level had no significant effect on either the growth performance or carcass characteristics The greater intake of digestible energy by the lambs fed calcium soaps of palm oil may account for the higher average daily gains and fatter carcasses. 


\section{REFERENCES}

Abdelhamid, A.M., A.F. Mehrez, A.E. Abdel- Khalek, E.A. Omer and M.A. Abou El- Hamed, 2003. Nutritional and physiological studies on Friesian calves fed protected fat and protein diets. 1: Growth performance and carcass traits. Egyptian J. Nutrition and Feeds, 6 (special Issue): 637- 648.

Abo-Donia, F.M.A., F.A. Salem and N.A.M. Soliman, 2003. Incorporation of refinning oil by- products in sheep diets. Egyptian J. Nutrition and Feeds, 6 (special Issue): 1279- 1299.

Aitken, A., J.C. Cassey, L. F. Penny and C. A. Voyls, 1962. Effect of drying temperature on the accelerated freeze drying pork. J. Sci. Fed, Agric., 13: 439. In: Meat science. Fourth Edition. PP. 224 - 246.

A.O.A.C., 1984. Official Methods of Analysis. $14^{\text {th }}$ Ed. Association of Official Analytical Chemists, Washington, D.C.

Bartle, S.J., R.L. Preston and M.F. Miller, 1994. Dietary energy source and density: Effect of roughage source, roughage equivalent, tallow level and steer type on feedlot performance and carcass characteristics. J. Anim. Sci., 72:1943- 1953.

Bendary, M.M., I.A. Abou- Selim, M.R.M. Moustafa, A.M Mahmoud and A.E.M. Khinizy, 1994. Performance of fattening buffalo calves fed different levels of fat for two different periods. Egyp. J.Anim. Prod. 31(suppl., 1) Issue: 613- 626.

Bock, B.J., D.L. Harmon, Jr. R.T. Brandt and J.E. Schneider, 1991. Fat source and calcium level effect on finishing steers performance, digestion and metabolism. J. Anim. Sci., 69:2211- 2224.

Byers, F. M., and G. T. Schelling, 1988. Lipids in ruminant nutrition. In: D. C. Church (ed.) The Ruminant Animal: Digestive Physiology and Nutrition. pp 298312. Prentice Hall, Englewood Cliffs, NJ.

Cameron, C.W. and D.E. Hogue, 1968. Effect of varying dietary corn oil and hay grain ratio on lamb growth and fat characteristics. J.Anim. Sci., 27: 553- 556.

Christie, W.W., 1981. Lipid metabolism in ruminant animals (Christie, W., ed). Pergamon Press, Oxford, UK.

Chrzaszcz, E., T.Kistowki, A. Korniewicz and M.H. Czarnik, 1995. Effect of rapeseed on the productivity, physiological values and carcass quality in calves. Roczniki, Naukone, Zootechniki (22) 1, 231- 249.

Doreau, M., A. Ferlay and Y. El-Meddah, 1993. Organic matter and nitrogen digestion by dairy cows fed calcium salts of rapeseed oil fatty acids or rapeseed oil. J.Anim.Sci., 71:499- 504.

Duncan, D.B., 1955. Multiple range and multiple F- test. Biometrics, 11: 1.

El-Bedawy, T.M., 1989. Fat in small ruminant nutrition, preliminary study. 2: Effect of fat inclusion on carcass characteristics of goats and sheep fed high concentrate diets. Third Egyptian British Conference on Animal, Fish and Poultry Production, Alex., 7- 10 October, Page: 401- 407.

El-Bedawy, T.M., 1995. Preparation of sunflower oil calcium soap as a protected fat and its use in ruminant nutrition. J. Agric. Sci., Mansoura University, 20: 231237.

El-Bedawy, T.M., M.A.I. Salem and E.A. Badr, 1996a. Effect of dietary fat on growth performance and carcass characteristics of finishing bulls. Egyp. J. Anim. Prod., 33 Suppl., Issue, 103- 111. 
El-Bedawy, T.M., Sabbah, M. Allam, A.F. El- Kholy and A.K. Basiony, 1996 b. Response of growing buffalo calves to fat containing rations. Egyp. J. Anim. Prod., 33 (2) 79- 88.

El-Bedawy, T.M., I. A. Gommaa, Sabbah M. Allam and F.M. Abo-Donia, 2004a. Production of calcium salts of fatty acid from soap-stock on semi industrial scale and its use in finishing rations of Friesian bulls. Egypt. J. Anim. Prod. 41.19-30.

El-Bedawy, T.M., M.A.I. Salem and A.S. Sami, 2004b. Calcium soaps in low or high roughage rations: 1- Effect on digestion, rumen metabolism, blood plasma lipids of growing-finishing bulls. Egypt. J Anim. Prod. 41.31-38.

El-Kholy, N.M., G.A. Baraghit, S.S. Omer, B.M. Ahmed and Kh.I. Zedan, 2003. Effect of different sources of dietary fat on performance, ingestive behavior and carcass traits of fattening buffalo calves. Egyptian J. Nutrition and Feeds, 6 (special Issue): 709- 725.

El-Meddah, Y., M. Doureau and D.B. Michalet, 1991. Interaction of lipid supply and carbohydrates in the diet of sheep with digestibility and ruminal digestion. J. Agric. Sci., (Camb.) 116: 437- 445.

Eweedah, N., L. Rozasa, J. Gundel and J. Varhegyi, 1997. Comparison of full fat soybean, sunflower seed and protected fat as supplements for their effect on the performance of growing finishing bulls and carcass fatty acid composition. Acta Veterinaria Hungarica, 45: 151- 163.

Ferlay, A., J. Chabrot, Y. El- Meddah and M. Doureau, 1993. Ruminal lipid balance and intestinal digestion by dairy cows fed calcium salts of rapeseed oil fatty acids or rapeseed oil. J. Anim.Sci., 71: 2237- 2245.

Grau, R. and R. Hamm, 1957. Mitteilung uber due bestimmungolet Wasser Bindung des Muskels. Zeitscrifs Fur Laben Smittle. Unterscu Chung Und forschung, 105 (6): 446. In: Meat science. Lawrie. R.A. Fourth Edition PP. 138- 139.

Haaland, G.L., J.K. Matsushima, D.E. Johnson and G.M. Ward, 1981. Effect of replacement of corn by protected tallow in a cattle finishing diet on animal performance and composition. J. Anim. Sci., 523:695- 708.

Henderson, W.D., D. E. Goll, H.H. Stomer and M.S. Walter, 1966. Effect of different measurement techniques and operators on bovine longissimus dorsi area J. Anim. Sci., 25: 334.

Huffman, R.P., R.A. Stock, M.H. Sindt and D.H. Shain, 1992. Effect of fat type and forage level on performance of finishing cattle. J.Anim. Sci., 70: 3889.

Ilian, MA., MA. Al- Awadi and AJ. Salman, 1988. Use of fat in diets of sheep in hot environments. 1: Effects on performance, carcass characteristics and lipid composition of plasma. Anim. Feed Sci. and Technology, 19: 4, 327- 341.

Kerley's, 2002. Feeding whole soybeans to cattle. A university of Missouri Research up date. Email: mosybean@ Socketis. Net.

Lough, D. S., M. B. Solomon, T. S. Rumsey, T. H. Elsasser, L. L. Slyter, S. Kahl, and G. P. Lynch, 1992. Effects of dietary canola seed and soy lecithin in highforage diets on cholesterol content and fatty acid composition of carcass tissues of growing ram lambs. J. Anim. Sci. 70:1153.

Maiga, H.A., D.J. Schingotethe, and F.C. Ludens, 1995. Evaluation of diets containing supplemental fat with different sources of carbohydrates for lactating dairy cows. J. Dairy Sci., 78: 1122- 1130. 
Mason, M.E. and G.R. Waller, 1964. Dimethoxy propane included transes terification of fats and oils in preparation of methyl esters for gas chromatographic analysis. Anal. Chem. 36:583.

Mc Cartor, M.M. and G.C. Smith, 1978. Effect of protected lipids on feedlot performance and carcass characteristics of short- fed steers. J. Anim. Sci.,47: 270.

Ngidi, M.E., S.C. Loerch, F.L. Fluharty, and D.L. Palmquist, 1990. Effects of calcium soaps of long - chain fatty acids on feedlot performance, carcass characteristics and ruminal metabolism of steers. J. Anim. Sci., 68: 2555- 2565.

O'Mary, C.C., L.M. Everett and A.D. Graig, 1979. Production and carcass characteristics of Angus and Charolais X Angus steers. J. Anim Sci., 48: 239.

Pinosa, M., S. Bovolenta and M. Maffei, 1992. Energy supplementation of straw based diets: The Effects of the addition of fatty acids soaps on rumen degradability digestibility and growth performance in heifers. Agricoltura Mediterranea, 122:1, 101- 108.

Plascencia, A., M. Estrada and R.A. Zinn, 1999. Influence of free fatty acid content on the feeding value of yellow grease in finishing diets for feedlot cattle. J. Anim. Sci., 77: 2603.

Snedecor, G.W. and W.G. Cochran, 1984. Statistical Methods. $6^{\text {th }}$ ed. Iowa state University Press. Ames, Lowa, U. S.A.

Solomon, M.B., G.P. Lynch, E. Paroczay, and S. Norton, 1991. Influence of rapeseed meal, whole rapeseed, and soybean meal on fatty acid composition and cholesterol content of muscle and adipose tissue from ram lambs. J. Anim. Sci. 69:4055.

Teixeira, AJC., JMT. De. Azpvedo, A. De-Silva. Dias and MT. De Azevedo, 1989. Influence of a protected diet on deposition in Serada Estrela X Churro Mondequeiro lambs. Forra-Jesy Produccion animal encondicciones extensivas. Revista- Pastos, 39: No Extraordinario, 407- 415.

Wettstein, H.R., F.Utter, M.R.L. Schneder and M. Kreuzer, 1999. Effect of rape lecithins on growth, carcass quality and body fat composition of bulls. Book of Abstracts of the 50 th Annual Meeting the European Association for Animal Production, Zurich, Switzerland 22- 26 August No.5 page 100.

White, T.W., L.D. Bunting, L.S. Sticker, F.G. Hembry and A.M. Saxton, 1992. Influence of fish meal and supplemental fat on performance of finishing steers exposed of moderate or high ambient temperatures J. Anim. Sci., 70: 3286- 3292.

Wu, Z. and D.L. Palmquist. (1991). Synthesis and biohydrogenation of fatty acids by ruminal microorganisms in vitro. J. Dairy Sci., 74: 3035

Wu, Z., A, Ohajuruka and D.L. Palmquist, 1991. Ruminal synthesis, biohydrogenation and digestibility of fatty acids by dairy cows. J. Dairy Sci., 74: 3025- 3034.

Zinn, R.A., 1989. Influence of level and source of dietary fat on its comparative feeding value in finishing diets for steers: feedlot cattle growth and performance. J.Anim. Sci., 67: 1029.

Zinn, R.A., 1992. Comparative feeding value of supplemental fat in steam- flaked wheat based finishing diets for feedlot steers. J. Anim. Sci., 70: 2959- 2969

Zinn, R.A. and A. Plascencia, 1996. Effects of forage level on the comparative feeding value of supplemental fat in growing- finishing diets for feedlot cattle. J. Anim. Sci., 74: 1194- 1201. 
تأثير مستويى الاهن المحسى و مواد العلف الخشنة على النمو وصفات الذبيحة للأغنام

طه محمد البداوى، محمد على إبراهيم سالم، سوسن منصور أحمد، حامد عبد العزيز على عمر

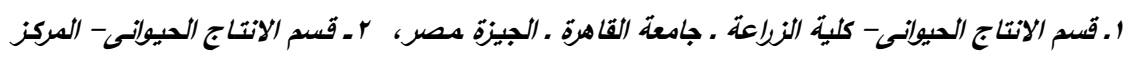

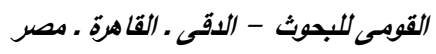

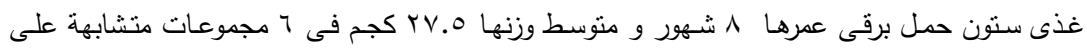

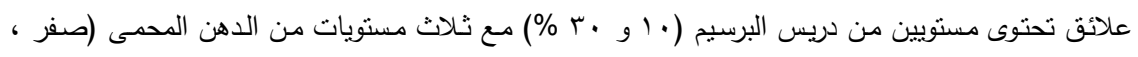

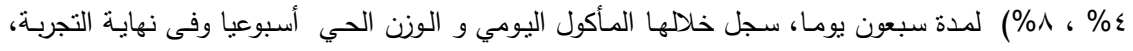

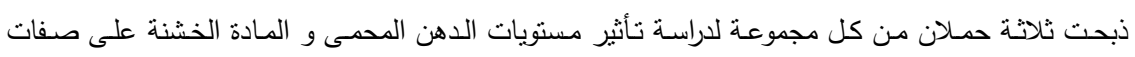

الذبيحة و جودة اللحم.

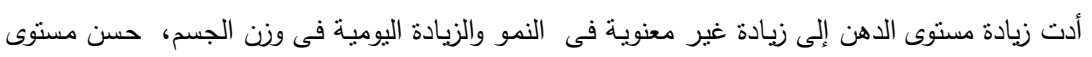

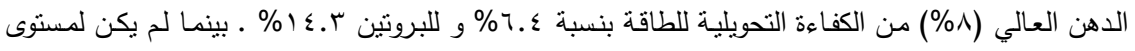

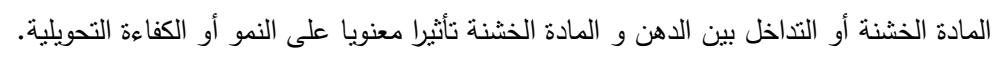

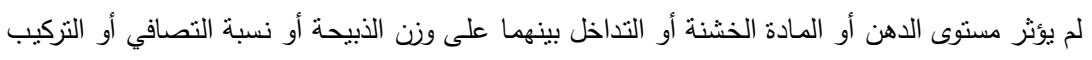

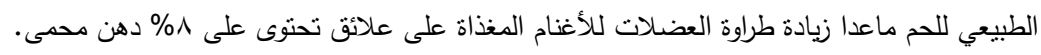

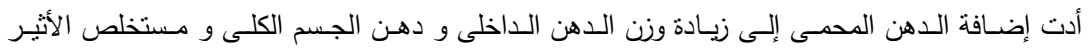

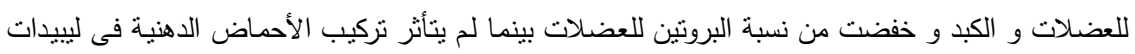

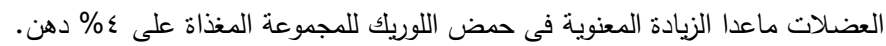

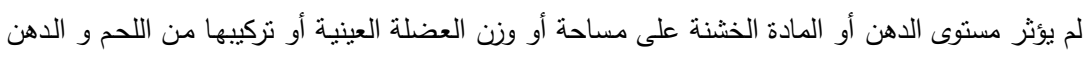

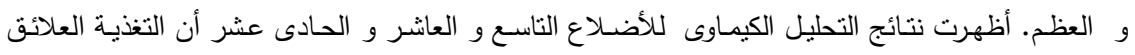

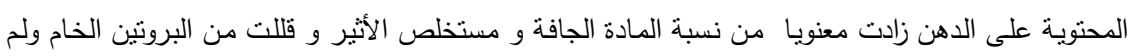
تتأثر نسبة الرماد الخام.

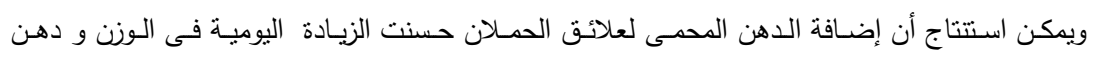

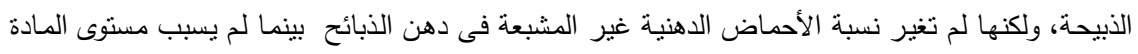

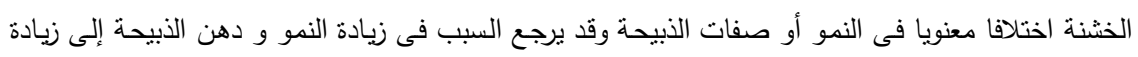

الطاقة المهضومة للحيوانات المغذاة على الدهن المحمى. 